\title{
A Century of Meatpacking and Packinghouse Labor in Chicago
}

\author{
A Review Essay
}

\section{GREGORY R. ZIEREN}

Chicago's Pride: The Stockyards, Packingtown, and Environs in the Nineteenth Century, by Louise Carroll Wade. Urbana: University of Illinois Press, 1987. xvi, 423 pp. Notes, maps, illustrations, essay on sources, index. $\$ 32.50$ cloth.

Work and Community in the Jungle: Chicago's Packinghouse Workers, 1894-1922, by James R. Barrett. The Working Class in American History. Champaign: University of Illinois Press, 1987 . xvi, 290 pp. Notes, tables, maps, illustrations, index. $\$ 24.95$ cloth.

Back of the Yards: The Making of a Local Democracy, by Robert A. Slayton. Chicago: University of Chicago Press, 1986. xiv, 278 pp. Illustrations, maps, appendix, notes, index. $\$ 22.00$ cloth.

THE FORTUNES of the State of Iowa have been intimately intertwined with its once premier industry, meatpacking, since Iowa emerged from territorial status. At first, meatpacking was a seasonal activity carried on mainly in Mississippi River towns like Keokuk, Burlington, and Muscatine. By the 1870s and 1880s Iowa ranked as the nation's leading hog producer, and when changes in transportation economics in the 1920s began to undercut the primacy of Chicago as "hog butcher of the world," lowa became the nation's leading meatpacking center. From the late 1930 s to the late 1960 s and early 1970 s Iowa's meatpacking industry prospered along with the rest of the American economy, vulnerable to temporary downturns at worst-or so it was once thought.

The 1980s have destroyed the illusion of permanent prosperity both for Iowa and for its meatpacking industry. As the industry has fallen on hard times, so have its unionized workers. 
Packinghouse workers, a longtime mainstay of the Iowa labor movement, have seen their once healthy wages for common labor cut to a fraction over minimum wage. Plant closings, employer offensives against unions, and the failure of employee ownership at Rath Packing Company in Waterloo complete the dismal picture of the Iowa meatpacking industry today.

While the Reagan era has treated the industry harshly, historical scholarship in the field, ironically, has blossomed. No first-rate study of the industry or its workers had appeared for decades, aside from David Brody's study of unionization, The Butcher Workmen, which appeared in 1964. Then in 1981 Mary Yeager's Competition and Regulation: The Development of Oligopoly in the Meat Packing Industry appeared; she examined the rise of the great Chicago meatpackers during the Progressive era to notoriety as "the world's greatest trust," in the phrase of one muckraker. In The Rise of the Midwestern Meat Packing Industry (1982), Mary Walsh looked at the entire midwestern region in the era before Chicago's meatpackers consolidated their control of the industry. The impact of changing transportation economics on the industry is one of the chief emphases of both books. Finally, Jimmy Skaggs's Prime Cut: Livestock Raising and Meatpacking in the U.S., 1607-1983 (1986) provided a comprehensive, if brief, history of both branches of the business. All three works fit in the categories of business or economic history.

In the past two years, three new works have appeared, deepening the historical scholarship on the meatpacking industry and its workers. These books, encompassing social, workingclass, technological, and environmental history, focus on Chicago's Union Stockyards and the neighborhood surrounding them in the nineteenth and early twentieth centuries when they were famous worldwide. Despite the local focus, none of the works is parochial in its scholarly concerns, and all of them broaden our understanding of the urban and social history of one of the nation's quintessential working-class districts. Issues of race, gender, ethnicity, and class, which appear in all three books, transcend the industrial and community relations of one industry, as do questions about the impact of industrialization on real people during the period of America's rise to mastery of the cycle of mass production and mass consumption. From these works, it is also clear why the business faltered in Chicago by the 
1920s, and leadership in the industry passed from Illinois to lowa.

LOUISE CARROLL WADE'S Chicago's Pride: The Stockyards and Environs in the Nineteenth Century chronicles the development of the meatpacking industry and the community surrounding the Yards from its earliest beginnings in the 1830 s to its fame as "eighth wonder of the world" during the Columbian Exhibition of 1893. It is an exhaustive study based on extensive primary research and secondary reading, and it is likely to stand as the definitive study of the development of the Town of Lake, the industrial suburb that eventually joined Chicago as Back of the Yards. Wade's range of topics is impressive: she considers so many issues in business and economic history, technological and environmental history, working-class and social history, that the work defies classification. Due to this diversity of themes, however, Wade occasionally loses focus on important historiographical questions.

Chicago's rise from frontier outpost in the 1830 s to one of the nation's major metropolises with a population of more than one hundred thousand in 1860 was inextricably bound up with railroads and the ancillary industries they spawned, like meatpacking. Originally merely one of many promising packing center sites in Illinois and along the Mississippi and Ohio rivers, the eventual triumph of railroads over forms of waterborne traffic by the 1850 s gave a tremendous boost to the fortunes of the meatpacking industry near Chicago as the city was transformed into the rail hub of the Middle West. The Town of Lake, crisscrossed by five railroads entering the city proper, grew to become Chicago's most important suburb.

At the end of the Civil War, several firms banded together to consolidate the various stockyards, rail sidings, and plants all over the South Side. The Union Stockyards crowned the efforts of these early packers and boosted the lead Chicago enjoyed over rival midwestern cities by facilitating the transshipment of animals eastward for slaughter elsewhere and by providing local packers with an immense market for livestock purchases for their own packing plants. With the greater volume of business at their doorsteps, major innovators in the industry, such as George Hammond and Gustavus Swift, sought the means to 
carry on the slaughter year-round by perfecting the refrigerated railroad car.

The stories of Swift's struggles to perfect the refrigerator car, the packers' disputes with railroad companies, and the initial resistance to dressed beef in eastern, urban markets are familiar ones, but Wade offers an excellent account of the local context for these industry developments. The economic and technological aspects of the transformation of the 1870s and 1880 s from serving a local market to providing processed meat for the national market are, however, treated with greater finesse in Mary Yeager's Competition and Regulation.

In the local context, Wade misses the opportunity to treat Swift, Morris, Armour, and the other leading packinghouse entrepreneurs as a business elite. There is suggestive evidence in the narrative that the group shared key characteristics of background, ethnicity, and experience, but Wade pursues none of these leads. What is especially puzzling about the neglect of these issues is the evidence from the footnotes that she has mastered the secondary literature on the subject of urban elites. But when she discusses the charitable undertakings of the Swift and Armour families, she seems to be engaging in a debate with the late Matthew Josephson on his famous Robber Barons thesis, even though the level of sophistication of discussions of the Captains of Industry has long since left Josephson behind. On the other hand, even sympathetic accounts, like Louis Swift's biography of his father, Gustavus, acknowledged that the public perceived these men as cold, hard, calculating, and grasping. Despite Wade's apparent effort to present the leading packinghouse entrepreneurs in a more favorable light, none of her evidence, aside from the charitable contributions, alters the more commonly held view or deals with the causes or consequences of the public perception.

A parallel analytical lapse weakens Wade's discussion of packinghouse workers. She offers a detailed and extremely wellresearched account of the beginnings of packinghouse trade unionism in the late 1870 s, analyzes the riots that sometimes accompanied the strikes, and paints the most compelling picture in print of the Knights of Labor organizing in the Yards in the mid$1880 \mathrm{~s}$. Her treatment of the succession of Irish, German, and Bohemian immigrant groups taking their places in the community 
and in the ranks of packinghouse labor is likewise commendable. The notes, again, display an impressive command of the "new labor history," but there is the same resolute avoidance of historiographical debate. As she indicates, workers were well paid, relative to many working-class trades, and the industry was rapidly expanding to provide greater opportunities for employment, yet those insights hardly answer the grievances of butchers who were attracted to trade unions because their jobs were being de-skilled, nor does that perspective address the problems of speed-up on the line, irregular employment, or the low wage rate for common labor.

Community building is a major theme of Wade's book. She examines the physical expansion of the district as developers laid out residential additions south of the Yards. Her account is sensitive to small differences in lot size, location, and proximity to the packinghouses, distinctions that translated into important community determinants for the residents. A German real estate dealer who preferred selling to members of his own nationality, the higher standard of respectability that skilled workers expected of their neighborhoods, and the degree to which ethnicity defined certain districts are all influences she considers. Within the ethnic enclave, she focuses on the voluntary associations that lent substance and permanence to community development. She chronicles the host of churches, religious societies, lodges, building and loan societies, athletic clubs, and political groups that made up the rich associational life of immigrant neighborhoods, especially German and Bohemian. She also shows how ethnicity influenced the political fortunes of local leaders and helped foster the final merger of the Town of Lake with Chicago in the annexation vote of 1889 .

Another strength of this work is its depiction of city officials and health authorities struggling with the consequences of industrial pollution with only the barest inkling of the germ theory of disease. Environmental issues figure prominently in each of the book's four major sections. In the hands of people like Wade, environmental history seems to be on the verge of coming of age as a major concern in historical scholarship. .

There is a great deal about Chicago's Pride to praise. The work is exhaustively researched, the level of detail is impressive, the scope of the author's reading in social, urban, labor, eco- 
nomic, and local history is enviable, and the work reads well. The book is not likely to be supplanted on any of these grounds. But the absence of a clearly defined thesis and the failure to address key historical questions takes the edge off this otherwise admirable piece of work.

JAMES R. BARRETT picks up where Wade leaves off, not only chronologically but also by treating the development of mass production in the early twentieth century as the impetus for the formation of working-class identity in Packingtown. As part of the series, The Working Class in American History, which is published by the University of Illinois Press and which includes the best of the "new labor history," Barrett's study, Work and Community in the Jungle: Chicago's Packinghouse Workers, 18941922, takes its place among the best of the best.

Meatpackers operated on slender profit margins because the cost of raw materials ate up an unusually large proportion of their total revenues. Thus management, in an effort to minimize the variable cost of labor, refined division of labor on the "disassembly line" to reduce the power and cost of skilled butchers and replace them with workers paid at common, unskilled labor rates. The thoroughgoing division of labor and control of the assembly line enabled the packers to boost productivity by increasing the pace and intensity of work.

Part and parcel of reducing labor costs was adjusting the size of the workforce to meet the changing market demand for meat and the supply of livestock delivered to the packers' gates. The seasonality of supply and demand and the packers' drive to reduce costs meant frequent layoffs in slack times and mandatory twelve-hour days and the hiring of casual labor at the plant gate in peak season. Packers found it easy to replace workers who had the temerity to object to their labor practices. As Barrett notes of the crowds that gathered each morning outside the plant awaiting the foreman's call, "wages and working conditions were affected as much by 'the man at the gate' as by what was happening inside the packinghouse" (30). By 1900 perhaps two-thirds of the workforce came from the ranks of common labor recruited from among the forty nationalities that called Packingtown home. 
Barrett's emphasis on the nature of the labor market and management policies is a refreshing change from the technological determinism that shapes so much of the literature on mass production industries. His review of the industry's history before 1900, for example, stresses, instead of technology, the interdependence of the packers' strategies for expanding markets and market control, and the cost savings realized in mass production. The notion of market-driven efficiencies is, of course, a familiar part of the story in economic history, but too often the other half of the equation-management policies on the shop floor to speed production and enhance labor productivity-is forgotten. Alfred Chandler's Visible Hand, for instance, treats the packers' achievements of the late nineteenth century as the victory of management's national marketing strategy, but does not mention packinghouse labor. Yet central to the lowering of unit costs through mass production in this industry, as in most others, was mastery of labor costs, and of skilled workers.

The waves of new immigrants from central and eastern Europe after 1900 played a vital role in achieving the packers' goal of absolute management discretion in labor policy. The German, Irish, and Bohemian workers who had formed the mainstay of the labor force in the period Wade describes gradually moved into the ranks of the more skilled, and more secure, jobs in the plants. The new immigrants took their places in the much larger pool of common labor. Employing the famous Dillingham Industrial Commission investigation of 1908, Barrett explores the role of the new immigrants in packinghouse labor and in the community of fifty thousand or so whose lives revolved around the bidding of the packers.

Contrasting old and new immigration, as the Commission did, Barrett first examines the more "Americanized," older workers who, by 1900 , had clearly become established as homeowners, dominated the ranks of skilled labor, and settled in stable communities. In contrast, newer immigrants of Polish, Lithuanian, and Slovakian origins supplied the industry's demand for unskilled, casual labor. The recent immigrants were often "birds of passage," young men who intended to make their fortunes in the New World and return to the Old, and they demonstrated little desire to become naturalized citizens. Before World War I they lived as boarders and roomers in a district characterized by 
overcrowding and high rates of communicable diseases like tuberculosis. Barrett paints a picture of an industrial slum featuring the noxious smells and pollution from the slaughterhouses, a picture first etched in Upton Sinclair's The Jungle. Overcoming the divisions between these newcomers and older, more highly skilled and more settled workers proved to be the central task of union organizers in the Back of the Yards after 1900.

These divisions in the community were intensified when the coming of World War I cut off traditional sources of labor from Europe, and the packers met their requirements for common labor by recruiting for the first time large numbers of rural, southern blacks, immigrant women, and Mexicans. Barrett's discussion of women's labor-in the home as mistress of the boarding house arrangement, and in the packinghouse as unskilled workers-shows the packers' intimate influence over social life and social roles in the community. His account of the importance of the boarding house system is the most lucid and compelling I have read.

In the second half of the book Barrett looks especially at two trade union organizing campaigns in the early twentieth century. Both campaigns ended in frustration and lost strikes. The significance that Barrett attaches to the strikes is what differentiates him and other new labor historians from their predecessors. Barrett's work is by no means an institutional history of the Amalgamated Meat Cutters and Butcher Workmen of North America, a subject fully treated by David Brody. Rather, what concerns Barrett is the light organizing drives and strikes cast on the community itself, on the process of class formation, and on the strengths and weaknesses of class solidarity. His findings are especially impressive in the case of the first, and lesser known, campaign between 1900 and 1904 .

The Amalgamated knew how the labor market for unskilled workers operated, too, and determined to exploit labor shortages that accompanied prosperity after the turn of the century. Barrett is able to show how older, skilled, Irish and German butchers, who had seen earlier organizing attempts founder on skill and ethnic divisions, transmitted their collective experience to newer immigrant workers. This time, the union undertook a comprehensive campaign, one that included not just wage increases for skilled workers but offered the prospect of an alter- 
native working life for all packinghouse workers. As Barrett explains, "the same work situation which represented such a high degree of rationalization from the packers' perspective brought chaos to the lives of their employees" (155). The power of collective resistance gripped skilled and unskilled workers, new and old immigrants, and achieved the goal of alleviating the harshness of packinghouse labor by winning recognition of seniority rights and slowing down the pace of the line. The packers relented temporarily as shop floor committees increased in strength and in their ability to control the work place.

Barrett then makes the critical connection between the shop floor and the community that makes his analysis so revealing. Higher wages and greater regularity of employment changed the very nature of life in Packingtown, if only briefly. Observers noted an increase in home buying among recent immigrants, the crime rate fell, and paupers seemed to be less prevalent along the streets of the district. University of Chicago investigators believed that union organizing and the new status of workers in the plants had helped stabilize social relations in the otherwise turbulent community. "The attainment of this higher standard of living," Barrett notes, "depended directly on the ability of workers to impose some order on the work process through organization at the point of production" (146).

The new order collapsed in the summer of 1904 when a recession swelled the ranks of the unemployed, and a hastily called and hastily considered nationwide strike against the entire industry failed. Although the strike marked the end of one organizing attempt, Barrett's account shows its significance for the struggle for workers' control and working-class solidarity in Packingtown.

An even more promising opportunity to organize arose when the U.S. entered the war in Europe in 1917. In addition to cutting off the supply of immigrant labor, the war created so much demand for meat that the entire pattern of industrial relations in the industry was open to restructuring. A union organizing drive in the summer of 1917 mounted by the new Stockyards Labor Council (SLC) and a rash of unofficial strikes persuaded the packers to accept government-sponsored mediation. Judge Samuel B. Alschuler's mediation hearings turned into a public relations debacle for the packers as their labor policies and the 
dismal living standards of their workers received unfavorable attention from the public.

The first Alschuler award represented almost a complete victory for the SLC as workers won increased wages, improved working conditions, and greater job security. But the quick victory concealed hidden costs. In Barrett's analysis, "Arbitration not only gave legitimacy to the union but also took away the right to strike and drew union officials into the efforts to discipline workers and maintain production" (200). The shop committees and militant job action of the earlier campaign were absent, and so was the solidarity that had united all workers. This time, moreover, the lines of division cut through not only nationality and skill, but race.

Although the unions had considerable success recruiting northern-born blacks and those with years of experience in factory work, they were less successful among southern blacks who had migrated to industrial cities in the East and Middle West to fill the labor shortages that the war-induced boom created between 1914 and 1918. Nevertheless, the potential for higher recruitment among blacks seemed real until the infamous Chicago race riots of July 1919 intervened to poison race relations in the packinghouses and neighborhoods of the South Side.

Barrett's account of these events revises and corrects William Tuttle's superb work, Race Riot. While Barrett agrees with Tuttle's assessment of the riot's devastating impact on racial peace in Chicago, he points out that no evidence links Back of the Yards residents to the racist attacks on blacks that occurred elsewhere. And union organizing, far from stimulating a racist reaction against blacks, helped knit the races together in a common enterprise. Barrett also explores the unfortunate action of southern blacks against white unions and the promotion of that attitude by the packers' financial contributions to wellplaced institutions in the black community like the Wabash Avenue YMCA and the Urban League. When the Alschuler mediation was suspended in 1921 and the Amalgamated called a strike to resist wage cuts, the inevitable result of poisoned race relations in early twentieth-century mass production industries happened: blacks were recruited to serve as strikebreakers, and the strike failed dismally. 
Barrett's final chapter exposes the offensive the packers mounted to wean the loyalty of workers, black and white, away from the union. The impetus for change was clear: "The experience of the wartime labor shortage and union organizing followed immediately by the postwar depression encouraged a fundamental reform of packinghouse labor" (243). In this case Barrett fails to cast his net wide enough. Attention to several instances of federal intervention in the industry - an embarrassing FTC investigation in 1917, the acceptance of a Justice Department Consent Decree in 1920 which limited the packers' auxiliary operations in other food lines and obliged them to divest themselves of stockyard and refrigerator car ownership, and the creation of a regulatory agency under the terms of the Packers and Stockyards Act of 1921-would have established the political and economic context of the industry in the 1920s.

On the other hand, his discussion of the welfare capitalist schemes to win workers' allegiance in the 1920s is excellent. Paid vacations, employee representation (company unions), stock options, insurance, and the introduction of personnel specialists suddenly became popular among the Big Four. The industry trade association, the Institute of American Meat Packers, worked for greater harmony in the industry and evinced a much greater concern for public relations. The new policies aimed at persuading workers, livestock growers, the consuming public, and the government of the packers' fundamental benevolence. Along with the severe unemployment caused by the recession of the early 1920s, racial divisions, and organizational splits among the unions, these new policies made short work of the Amalgamated during the winter of 1921-22.

Barrett, in the finest tradition of his mentor, David Montgomery, has written the best existing work on packinghouse labor, and one of the two or three finest studies of the labor movement in the early twentieth century. Work and Community in the Jungle should be a contender for the Taft prize or a similar award.

THE MOST INNOVATIVE of the three books chronicling Packingtown's history is Robert Slayton's Back of the Yards: The Making of a Local Democracy. Slayton's final chapters present a historical account of the two institutions which in the 1930s 
finally brought together the fragmented, ethnically divided workforce: the Back of the Yards Neighborhood Council (BYNC) and the CIO's Packinghouse Workers Organizing Committee (PWOC). Most of the book, however, is not a traditional historical account of institutions; rather, it might best be described as urban ethnography. It is reminiscent of the work of another anthropologist-turned-historian, Anthony F. C. Wallace, or of Joseph Barton, Slayton's adviser. In the best anthropological tradition of scholars such as Oscar Lewis, Slayton demonstrates a sophisticated use of oral history as a source for historical scholarship. The methodology of urban anthropology, when applied to historical and literate communities, yields detailed and satisfying portraits of community institutions, life stages, sex roles, ethnicity, and work. Yet, for all of the richness of the collective portraits, the methodology seems incapable of ordering them in a causal and chronological fashion so that the reader can achieve a sense of a moving picture with beginning, middle, and end.

Slayton chose the concept of community to unify the thematic chapters of oral testimony. There is profound irony in that choice. The famous Chicago School of urban sociologists and social workers from the early twentieth century based their ideas of community lost and urban anomie, in part, on the social disorder and decay they found in Chicago's immigrant, workingclass wards. Slayton, on the other hand, finds community precisely where the earlier generation found its absence. In this, Slayton is participating in a larger trend. Since at least the $1960 \mathrm{~s}$ historical and sociological scholarship has been moving toward a more comprehensive, if less well delineated, concept of community. The risk now is that any random collection of people may come to be treated as a community. When that happens, the term means everything and nothing.

Slayton defines his notion of community more rigorously, however. For him, community must include (1) a network of interpersonal ties providing sociability and support; (2) residence in a common locality; and (3) solidarity of sentiment and activity. Packingtown residents, in their quest for "stability and order," relied on "a small, dependable group of friends and relatives who could be trusted in all circumstances and could be relied on for any support" (9). To transcend the structural and 
static elements of this definition, Slayton introduces the quest for democracy as the dynamic force that finally created the BYNC in the late 1930s. The result is a community and ethnic study that, like the work of the scholars who have influenced him-Herbert Gutman, Victor Greene, Oscar Handlin, Moses Rischin, and John Bodnar-adds an invaluable dimension to the scholarship of the American experience.

Before undertaking to explain how Packingtown was transformed, Slayton explores what he terms "arenas of Life," essentially the day-to-day existence of ordinary men, women, and children in the early twentieth century. Here the unique advantages of oral history over more traditional historical sources are put to their best use. Slayton's correspondents recalled childhood experiences of games, sports, parochial schools, movies, and dances. The socialization process of the second generation of Slavic immigrants included healthy doses of religious and ethical training, as well as the inculcation of tradition, native culture, and language. By the age of sixteen, children left school, began looking for jobs, and were ready to assume the burdens of the next "arena," adulthood. Much of Slayton's work here resembles David Nasaw's Children of the City, but Slayton's account is all the more vivid because it derives primarily from the memories of working-class children and is specific to the Back of the Yards.

The description of women's roles as the anchor of the household and "custodian of tradition" is especially compelling. "The household lent stability to the social order," Slayton explains. "It was a haven from the unpredictable packers and the industrial system. It was the private place where the old ways remained in force" (75). Women recalling their own or their mothers' daily lives recounted an endless round of toil: washing, cleaning, ironing, shopping, mending, baking, cooking, and child care. Only Sunday remained for recreation, visiting relatives, and attending church. Women extended their domain outside the home only to the Catholic church with its fundraising drives, raffles, bingo, bazaars, and sewing circles. They also met to exchange community news and gossip at the hundreds of small groceries and butcher shops, each of which served fifty or so families regularly, and which routinely extended credit for the week's purchases. Women, of course, also controlled the 
family budget. Unfortunately, Slayton's focus on the household and traditional women's roles must come at the expense of considering wage-earning women, who are relegated in his account to the margin of prematrimony. Barrett's account is fuller and better informed on women's work in the packinghouses.

Work is central to Slayton's consideration of men's roles, especially the contradiction between the power patriarchy exercised in the home and the powerlessness male workers felt in the packers' domain. Workers resolved the tension between the two roles by covert resistance, such as stealing food, smoking on the job, or slacking off work when the foreman wasn't looking; overt resistance took place mainly during the union drives and strikes that Barrett describes. More commonly, Slayton believes, workers sought refuge from the work pace, smells, diseases, and dangers of packinghouse labor in private, male-oriented institutions like saloons, social clubs, and pool halls, and, of course, at home. Slayton does not develop this theme very far, but his descriptions add informative details to the treatments of workingclass leisure activities in Roy Rosenzweig's Eight Hours for What We Will and Francis Couvares's The Remaking of Pittsburgh.

The richly detailed descriptions of everyday life and the urban anthropological appreciation of structure and function serve Slayton less well in the second half of the book, where he sets forth a three-stage scheme of community development from fragmented to unified, or on his scale, Segmented Group, Nationalist Enclave, and Back of the Yards Neighborhood Council. Some such pattern may be necessary to explain the community's evolution over forty years, but Slayton's elaboration omits the sense of historical dynamic and human agency in the change. Causality is not central to Slayton's description of social, occupational, and gender roles, and that seems appropriate; causal chains are vital, however, in explaining transitions from one stage of community development to the next, but they are missing from Slayton's account. Precise chronology, likewise, would seem unimportant in addressing the issues in the first half of the book, but chronology must be considered in recounting the succession of union organizing drives in the Yards between 1933 and 1939 before the CIO's PWOC finally met success at Armour. Although Slayton offers a general chronol- 
ogy for the three stages, they seem like static categories imposed on an indifferent calendar.

In the first stage, segmented groups of fifty to one hundred individuals took their inspiration from the village experiences of immigrants from central and eastern Europe. Based on shared origin, religion, kinship ties, and language, these segmented groups were so small that historians and sociologists have simply overlooked them. The groups, nonetheless, had enough internal cohesion to establish social norms, pool resources and information, and offer protection for their members. I suspect that Slayton is correct in seeing the segmented group as a primary reference point for many immigrants' lives. The danger is that the groups may appear so atomized as to be incapable of any significant collective action, and Barrett has shown quite the reverse in his discussion of the 1904 strike and the Stockyards Labor Council in 1917. Furthermore, Slayton would have to offer proof of his assertion about shared village origin. Perhaps his usage of the term village is metaphorical rather than geographic and specific, but something more substantial seems to be implied when he notes, "the first immigrants defined themselves simply as villagers and had a great deal of experience in using that personal and social identification to create ties of community" (113).

Other than the leaders recruited from the ranks of parish priests or small businessmen, stable community development crystallized around the homeowners of Packingtown. As Slayton elaborates, "Home owners were the group that all leaders appealed to because they had the most to gain from a stable community" (127). In other words, from among the multitudes drawn by job opportunities to the packinghouses, permanent residents eventually sorted themselves out from the stream of transients and fulfilled the minimum requirement of community building of some degree of residential permanence. The distinction is often lost in studies of social and geographic mobility, such as Howard Chudacoff's Mobile American or Stephen Thernstrom's Poverty and Progress.

The process of ethnic and residential sifting and sorting brought together the segmented groups before World War I into nationalist enclaves, the basic unit of community definition before the depression. The process of congealing into larger 
groups, in Slayton's account, owed its origins to the centralizing and Americanizing pressures of the Catholic church hierarchy. Parishes lost their autonomy and exclusive control over church property, English replaced various Slavic languages as the means of instruction, and the perpetuation of cherished traditions and cultures seemed at risk. In reaction against the trends, parish priests turned their congregations to nationalism as a method of buttressing local clerical power. "In doing so, they caused their parishioners to redefine their identity and thereby helped to restructure the basic unit of community in the urban industrial neighborhood" (137). Parishioners, in turn, organized their associations along nationalistic and linguistic lines. The emphasis on national identity united thousands in a common heritage and bridged geographical borders to reach countrymen and women in other neighborhoods of Chicago and beyond. But for all the power of nationalism to unite Slavic immigrants and their children, nationality also provided a divisive force against which trade unionism and the local Socialist party struggled in vain. As Barrett shows, nationalistic divisions were a potent weapon in the packers' efforts to defeat collective action.

One of Slayton's best chapters lays bare the exploitation of nationalist divisions by the bosses of Chicago's Democratic party machine. The account confirms Robert K. Merton's depiction of Fourteenth Ward politics as a giant swap meet where votes were traded for services and jobs for local residents. Slayton's account of the unsuccessful rebellion of Polish would-be officeholders in the 1940s against the Irish who dominated ward politics, and the Poles' subsequent reconciliation with the machine, shows the fine balancing act Irish politicos performed, keeping various ethnic groups contented with services and minor posts while retaining control in their own hands. While this story will be familiar to friends and enemies of the late Mayor Richard J. Daley or readers of Mike Royko's Boss, Slayton's chapter makes for especially compelling reading because he so skillfully and carefully discloses the nature of the relationship between political machines and the communities they "served."

Slayton's notion of the role of the nationalist enclave in the stages of community development, on the other hand, suffers from too narrow a focus on what happens within the bounds of 
the Back of the Yards. Aside from the religious incentive fostered by parish priests turning to nationalism to boost their own authority, Slayton offers no reason to explain the transition from segmented group to nationalist enclave. In passing he mentions the oppression of subject minorities within the AustroHungarian Empire on the eve of World War I. But he fails to point out that the agitation of Czechs, Lithuanians, and Poles in ethnic cities like Chicago, Buffalo, Detroit, and Cleveland was in part responsible for the emergence of Poland, Czechoslovakia, and Lithuania after the war. The preservation of these states against powerful European neighbors like Germany and the Soviet Union helped impart a stronger sense of nationality among their immigrant countrymen and women in the United States. Slayton did only minimal research in the Slavic press of Chicago, a difficult task, admittedly, but one that might be necessary to sustain some of his conclusions about the nature of nationalist enclaves. This book has important things to offer to historians of immigration, yet it also underlines how much remains to be done.

The final chapters trace the creation and successful operation of the Back of the Yards Neighborhood Council (BYNC). This story is an important one for several reasons. BYNC was a pioneering example of community organizing and launched the career of the most famous community organizer of them all, Saul Alinsky. More important, BYNC was an innovator in creating the sort of urban democratic institutions that would become one of the mainstays of the pluralist New-Deal style welfare state.

The impetus for the formation of the BYNC was the depression. Straining the resources of church and nationalist clubs in the Yards, the scope of the disaster called forth a cooperative effort that went beyond the limitations of the nationalist enclaves of the teens and twenties. The challenge could be met only by joining the various religious, ethnic, and political groups in an organization that, in the founder's words, "used residents' knowledge to identify their community's needs and then marshalled their energies to find solutions" (192). The BYNC shrewdly chose to address problems that affected the entire community, and it took care to ensure that its projects did not pose a threat to existing groups. As Slayton writes, “The BYNC 
did not replace the nationalist groups and it never tried to; what it provided was a place where, once a month, everyone in the neighborhood could join together to try to wrest from outside authorities the resources they all needed" (201).

The CIO's PWOC simultaneously started organizing among packinghouse workers. Each group appreciated the virtues of cooperation with the other. The PWOC's connections with the BYNC helped win the endorsement of Chicago's Bishop Sheil and younger Catholic priests in the district for the Armour strike of 1939, the prelude to victory in the entire Chicago packinghouse industry.

There is a certain discontinuity between the chapters on the BYNC and the earlier portions of the book. If the depression was indeed the formative influence for the establishment of the BYNC, why was nothing attempted until 1937? How important to the success of the BYNC were the various New Deal programs designed to promote relief and recovery? It is not uncommon for historians to start with a problem or institution and work backward toward the roots. If this was the procedure Slayton followed, he does not entirely persuade me that the steps along the way led to the conclusion he sees, an achievement of democracy in the Back of the Yards.

Despite its problems, Slayton's book is innovative and original. It has the immediacy of personal experience expressed in lively, everyday speech, and reflects the best uses of oral history as a source. The book is well written and easily retains the reader's interest (despite some egregious proofreading errors).

With the almost simultaneous publication of these three books, a vital chapter has been added to the history of that most American of cities, Chicago; and the writing of social and labor history has been enriched. The scholarship displayed in these three books should serve as models for investigations of the packinghouse industry in Iowa and other important centers such as Kansas City and Omaha. Though the industry may not see its way out of its present difficulties any time soon, the historical inquiry into its roots and problems is alive and well. 
Copyright of Annals of Iowa is the property of State of Iowa, by \& through the State Historical Society of Iowa and its content may not be copied or emailed to multiple sites or posted to a listserv without the copyright holder's express written permission. However, users may print, download, or email articles for individual use. 